\title{
PENYAKIT KARIES GIGI PADA PASIEN PENGUNJUNG PUSKESMAS DOLODUO BERDASARKAN UMUR TAHUN 2016-2017
}

\author{
Mustapa Bidjuni \\ Jurusan Keperawatan Gigi Poltekkes Manado. Jl. R.W. Mongisidi Malalayang II Kota Manado \\ Email : mustapabidjuni@gmail.com
}

\begin{abstract}
ABSTRAK
Latar belakang : Karies merupakan suatu penyakit pada jaringan keras gigi, yaitu email, dentin dan sementum yang disebabkan aktifitas jasat renik yang ada dalam suatu karbohidrat yang diragikan. Prevalensi Indeks DMF-T nasional yaitu 4.6 sedangkan indeks DMF-T Sulawesi Utara yaitu 5,4. Penelitian ini bertujuan untuk mengetahui Gambaran Penyakit Karies Gigi Pada Pasien Pengunjung Puskesmas Doloduo Berdasarkan Umur Tahun 20162017. Metode : Jenis penelitian menggunakan metode deskriptif menggunakan data sekunder berupa buku register kunjungan pasien dipoliklink gigi Puskesmas Doloduo selang tahun 2016- 2017. Sampel penelitian berjumlah 630 pasien pengambilan sampel dari total populasi. Data yang telah dikumpulkan kemudian ditabulasi dan disajikan dalam tabel distribusi frekuensi persentase. Hasil: Hasil penelitian menunjukkan bahwa distribusi kunjungan penyakit karies gigi tahun 2016 yang paling tinggi yaitu berusia 22-28 tahun 24,08\% dari total kunjungan 270 pasien, Tahun 20117 yang paling tinggi kunjungan pasien penyakit karies gigi yaitu berusiua 29-34 tahun berjumlah 19,54\% dari total kunjungan 360 pasien. Kesimpulan: penelitian ini menunjukkan bahwa jumlah kunjungan pasien penyakit karies gigi terjadi peningkatan dari tahun 2016 sampai 2017.
\end{abstract}

\section{Kata Kunci : Karies Gigi, Pengunjung, Puskesmas}

\begin{abstract}
Background: Caries is a disease of the hard tissue of the teeth, namely e-mail, dentine and cementum, which is caused by the tiny maneuvering activity that is present in a carbohydrate that is distributed. The prevalence of the national DMF-T Index is 4.6 while the North Sulawesi DMF-T index is 5.4). This study aims to determine the description of dental caries in patients with visitors to Doloduo health center based on age 2016-2017. Method: This type of research uses descriptive methods using secondary data in the form of patient visit register books at Doloduo Community Health Center tooth link in the intervals of 2016 to 2017. The study sample consisted of 630 patients taking samples from the total population. Data that has been collected is then tabulated and presented in the percentage frequency distribution table. Results. The results showed that the highest distribution of dental caries disease visits in 2016 was $22-28$ years old, $24.08 \%$ of the total 270 patient visits, in 20117 the highest number of visits to dental caries patients was 29-34 years, totaling $19.54 \%$ of total visits of 360 patients. Conclusion: this study shows that the number of dental caries patients' visits has increased from 2016 to 2017.
\end{abstract}

Keywords: Dental Caries, Visitors, Puskesmas 


\section{PENDAHULUAN}

Karies merupakan suatu penyakit pada jaringan keras gigi, yaitu email, dentin dan sementum yang disebabkan aktifitas jasat renik yang ada dalam suatu karbohidrat yang diragikan. Proses karies ditandai dengan terjadinya demineralisasi pada jaringan keras gigi, diikuti dengan kerusakan pada bahan organiknya. Hal ini akan menyebabkan terjadinya infasi bakteri dan kerusakan pada jaringan pulpa serta penyebaran infeksi ke jaringan periapikal dan menimbulkan rasa nyeri. Sampai skarang, karies masih merupakan masalah kesehatan baik di negara maju maupun dinegara-negara berkembang ${ }^{1 .}$ Karies gigi adalah penyakit jaringan gigi yang ditandai dengan kerusakan jaringan, dimulai dari permukaan gigi (ceruk,fisura, dan daerah interdental proksimal) meluas kearah pulpa. Karies gigi terdapat diseluruh dunia, tanpa memandang umur, bangsa ataupun keadaan ekonomi. Menurut penelitian di negara-negara Eropa, Amerika, dan Asia termasuk Indonesia ternyata 80-95 persen anak di bawah usia 18 tahun terserang karies gigi ${ }^{2}$

Riset Kesehatan Dasar tahun 2013 dilakukan pengumpulan data berbagai indikator kesehatan gigi dan mulut masyarakat, dengan cara wawancara dan observasi dengan menggunakan alat genggam (kaca mulut) dan prevalensi nasional masalah gigi dan mulut adalah $25,9 \%$, sebanyak 14 provinsi mempunyai masalah gigi dan mulut yaitu angka nasional. Prevalansi nasional indeks DMFT yaitu 4,6 sebanyak 15 provinsi memiliki prevalansi di atas prevalansi nasional. Indeks DMF-T lebih tinggi pada perempuan (5.0) dibanding laki-laki $(4,1)$.Indeks DMF-T Propinsi Sulawesi Utara $5,4^{3}$.
Karies gigi dapat diartikan sebagai suatu proses patologi paskaerupsi yang terlokalisasi dan disebabkan oleh faktor luar. Proses ini dimulai dengan kerusakan jaringan enamel yang menjadi lunak dan pada akhirnya menyebabkan terjadinya karies ${ }^{4}$. Proses terjadinya karies gigi dimulai dengan adanya plak dipermukaan gigi, sucrose (gula) dari sisa makanan dan bakteri berproses menempel pada waktu tertentu yang berubah menjadi asam laktat yang akan menurunkan $\mathrm{pH}$ mulut menjadi kritis $(5,5)$ yang akan menyebabkan demineralisasi enamel berlanjut karies gigi ${ }^{1}$ Selain faktor Umur, Karies Gigi dipengaruhi beberapa hal yang dapat mempengaruhi terjadinya karies gigi pada manusia ${ }^{2}$ Keturunan; Dari suatu penelitian terdapat 12 pasang orang tua dengan keadaan gigi yang baik, terlihat bahwa anak-anak dari 11 pasang orang tua memiliki keadaan gigi yang cukup baik. Ras; Keadaan tulang rahang suatu ras bangsa mungkin berhubungan dengan persentasi karies yang semakin meningkat atau menurun. Misalnya pada ras tertentu dengan rahang yang sempit sehingga gigigeliginya pada rahang sering tumbuh tidak teratur.Dengan keadaan gigi yang tidak teratur ini akan mempersukar pembersihan gigi, dan ini akan mempertinggi karies pada ras tertentu. Jenis kelamin; Dari pengalaman yang dilakukan oleh Milhahn Turkehim pada gigi M1, didapat hasil presentasi karies gigi pada wanita lebih tinggi dibanding dengan pria. Usia; Sepanjang hidup dikenal 3 fase umur dilihat darim sudut gigi-geligi: 1). Periode gigi campuran, di sini molar 1 paling sering terkena karies. 2). Periode pubertas (remaja) usia antara 14-20 tahun,pada masa pubertas terjadi perubahan hormonal yang dapat menimbulkan pembengkakan gusi, sehinga kebersihan mulut menjadi 
kurang terjaga. Hal ini yang menyebabkan prentasi karies lebih tinggi. 3). Usia antara 40-50 tahun; pada usia ini sudah terjadi retraksi atau menurunnya gusi dan papil sehinggah sisa-sisa makanan sering lebih sukar dibersihkan. Pencegahan Karies Gigi:1). Kurangi komsumsi makanan manis dan mudah melekat pada gigi seperti permen dan coklat. 2). Menggosok gigi secara teratur dan benar. Sebaiknya dilakukan pagi dan menjelang tidur. Lebih baik lagi dilakukan tiap usai makan. Dalam hal ini pililah sikat gigi yang berbuluh halus dan pasta gigi yang mengandung fluor.Biasakan pula berkumur-kumur setelah makan makanan manis. 3). Siapkan makanan yang kaya akan kalsium(seperti ikan dan susu), fluor (sayur, daging dan teh), Vitamin A (wortel), Vitamin C (jeruk), Vitamin D (susu), Vitamin E (kecamba). 4). Menjaga hygiene gigi dan mulut. Bila ada karang gigi sebaiknya dibawa ke dokter untuk dibersihkan Sebaiknya pula memeriksakan gigi tiap enam bulan sekali. ${ }^{5}$

Umur adalah satuan waktu yang mengukur waktu keberadaan suatu benda atau mahluk, baik yang hidup maupun yang mati. WHO merekomendasikan kelompok umur 5 tahun untuk gigi susu dan 12, 15, 35-44 dan 65-74 tahun untuk gigi permanen.Jumlah subjek yang diperiksa untuk setip kelompok umur minimal 25-50 orang untuk setiap kelompok. Lima tahun anak-anak seharusnya diperiksa diantara ulang tahun mereka yang ke-5 dan 6 Umur ini menjadi umur indek untuk gigi susu karena tingkat karies pada kelompok umur ini lebih cepat berubah dari pada gigi permanen sekaligus umur5 tahun merupakan umur anak mulai sekolah. Namun, dinegara yang usia masuk sekolahnya lebih lambat, dapat digunakan umur 6 atau 7 tahun sebagai umur indeksnya. Kelompok umur ini, sebaiknya gigi susu yang hilang tidak dimasukan ke dalam skor $\mathrm{m}$ (missing) karena kesulitan membedakan penyebab kehilangan gigi, apakah karena sudah waktunya tanggal atau dicabut karena karies. 12 tahun kelompok umur ini penting untuk diperiksa karena umumnya anak-anak meninggalkan bangku sekolah pada umur 12 tahun.Selain itu, semua gigi permanen diperkirakan sudah erupsi pada kelompok umur ini kecuali gigi Molar. Gigi berdasarkan umur 12 tahun ditetapkan sebagai umur pemantauan global (global monitoring age) untuk karies lima belas tahun Pada kelompok umur ini dianggap bahwa gigi permanen sudah terekspos dengan lingkungan mulut selama 3-9 tahun,sehingga pengukuran prevalensi karies dianggap lebih bermakna dibandingkan usia 12 tahun. Umur ini juga merupakan usia untuk pengukuran indikator penyakit periodontal pada remaja. 35-44 tahun (rerata $=40$ tahun). Kelompok umur ini merupakan kelompok umur standar untuk memonitor kesehatan orang dewasa dalam hal efek karies, tingkat keparahan penyakit periodontal, dan efek pelayanank esehatan gigi yang diberikan. 65-74 tahun. (rerata= 70 tahun). Kelompok umur ini lebih penting sehubungan dengan adanya perubahan distribusi umur dan bertambahnya umur harapan hidup yang terjadi di semua Negara. Data dari kelompok umur ini diperlukan untuk membuat perencanaan pelayanan kesehatan bagi manula dan memantau semua efek pelayanan rongga mulut yang diberikan. ${ }^{6}$

\section{METODE}

Jenis penelitian yang digunakan yaitu penelitian deskriptif menggunakan 
data sekunder berupa buku register penggunjung poliklinik gigi puskesmas. Populasi dalam penelitian yaitu data seluruh pasien yang memeriksakan gigi ke Poliklinik Gigi Puskesmas Doloduo Kecamatan Dumoga Barat Kabupaten Bolaang Mongondow mulai tahun 20162017 yang berjumlah 630 pasien diambil secara total populasi. Teknik pengumpulan data dengan memnggunakan data sekunder melalui buku register pasien tahu 20162017. Data yang terkumpul disajikan dalam bentuk tabel distribusi frekuensi disertai penjelasan.

\section{HASIL}

Hasil penelitian ini menunjukkan bahwa penyakit karies gigi berdasarkan Umur dipoliklinik gigi tahun 2016 paling tinggi umur 22-28 tahun 65 pasien $(24,08 \%)$ dari total kunjungan berjumlah 270 pasien sedangkan pada tahu 2017 menunjukkan menunjukkan bahwa Penyakit Karies Gigi Berdasarkan Umur di Poliklinik Gigi tahun 2017 yaitu Umur 29-35 tahun berjumlah 70 pasien $(19,54 \%)$ dari total kunjungan berjumlah 360 pasien

\section{PEMBAHASAN}

Penelitian ini dilakukan di Puskesmas Doloduo Kecamatan Dumoga Barat Kabupaten Bolaang Mongondow. Pada bagian ini akan dijelaskan karakteristik Penyakit Karies Gigi berdasarkan umur tahun 2016 - 2017.

Dari hasil penelitian menunjukkan bahwa penyakit karies gigi berdasarkan umur 15 - 70 tahun pada tahun 2016 terjadi pada usia 22-28 tahun dibandingkan rentang umur lainnya baik pada tahun 2016 dengan persentase sebesar 24,08\%atau sebanyak 65 pasien dan pada tahun 2017 pada 29-35 tahun dengan persentase sebesar 19,54\%atau sebanyak 70 pasiensecara keseluruhan tahun 2016-2017 diperoleh jumlah pasien yang mengalami karies gigi sebanyak 630 pasien

Perbedaan ini lebih disebabkan karena sebagian besar penduduk wilayah Puskesmas Doloduo bekerja sebagai petambang emas dan pada rentan umur 2935 tahun merupakan usia produktif untuk bekerja di wilayah tersebut. Para pekerja tambang seringkali mengabaikan kebersihan gigi dan mulut karena sibuk dengan pekerjaannya tersebut sehingga memudahkan perlekatandari plakdan memperbesar terjadinya karies. Penelitian sebelumnya yang sejalan dengan penelitian ini yang dilakukan oleh Notohartojo (2015), mengenai Pemeriksaan Karies Gigi pada Beberapa Kelompok Usia oleh Petugas dengan Latar Belakang Berbeda di Provinsi Kalimantan Barat menunjukan bahwa pada responden dengan usia 18 - 44 tahun, diperoleh $D M F-T$ sebesar $9,82 \%$ atau 10 gigi yang mengalami lubang, dicabut, dan ditambal karena karies gigi. ${ }^{7}$ Penelitian epidemiologis menunjukan terjadi peningkatan prevalensi karies sejalan dengan bertambahnya umur. Gigi yang paling akhir erupsi lebih rentan terhadap karies. Kerentanan ini meningkat karena sulitnya membersihkan gigi yang sedang erupsi sampai gigi tersebut mencapai dataran oklusal dan beroklusi dengan gigi antagonisnya. Anak-anak mempunyai resiko karies yang paling tinggi ketika gigi mereka baru erupsi sedangkan orangtua lebih berisiko terhadap terjadinya karies $\mathrm{akar}^{7}$. Berdasarkan penelitian sebelumnya yang dilakukan oleh Ramayanti (2013). 
mengenai peran makanan terhadap kejadian karies gigi, maka dapat diketahui bahwa karbohidrat adalah bahan yang sangat kariogenik. Dengan demikian maka semua golongan masyarakat rentan terhadap terjadinya karies gigi karena tidak lepas dari makanan nasi yang mengandung karbohidrat paling tinggi. Penelitian ini pula menunjukan cara-cara pencegahan karies gigi yang diakibatkan oleh karbohidrat, salah satunya adalah dengan modifikasi diet yaitu dengan mengkonsumsi makanan kariostatik seperti lemak, protein dan fluor ${ }^{8}$.

\section{KESIMPULAN}

Kesimpulan akhir dari penelitian tentang gambaran penyakit karies gigi berdasarkan Umurdi Poliklinik Gigi Puskesmas Doloduo Kecamatan Dumoga Barat Kabupaten Bolaang Mongondow: Penyakit karies gigi berdasarkan umur lebih tinggi pada umur 22-28 tahun yaitu tahun 2016 jumlah 65 pasien $(24,08 \%)$. Penyakit karies gigi pada tahun 2017 didominasi oleh umur 29-35 tahun jumlah 70 pasien (19,54\%)dan mengalami kenaikan dibandingkan tahun sebelumnya.

\section{SARAN}

Kepada Puskesmas Doloduo khusus petugas kesehatan gigi agar lebih meningkatkan pelayanan kesehatan gigi meliputi kegiatanpromotif dan preventif sehingga masyarakat dapat mengetahui resiko yang di timbulkan jika tidak memelihara kebersihan gigi dan mulut. Menerapkan ilmu yang didapat selama Pendidikan dengan cara membimbing masyarakat terutama kelompok rawan masalah kesehatangigi dan mulut, dilatih agar terbiasa memanfaatkan fasilitas kesehatan gigi dan mulut yang sudah disediakan oleh pemerintah atau swasta, sehingga kerusakan yangterjadi pada gigi sedini mungkin.

\section{DAFTAR PUSTAKA}

1. Pintauli S dan Hamada T. (2008). Menuju Gigi dan Mulut Sehat. USU Press. Medan

2. Tarigan, (2013). Karies Gigi. Edisi 2.EGC. Jakarta

3. Bapelitbangkes. (2013)Riset Kesehatan Dasar . Kementerian RI . Jakarta.

4. Bahar A.(2011).Paradikma Baru Pencegahan Karies Gigi. FEUI. Jakarta

5. Kidd ,Bechal. (1992). Dasar-dasar Karies Penyakit dan Penanggulangannya. EGC. Jakarta.

6. Sutrisna,.(2010).Pengantar Metode Epidemiologi.PT. Dian Rakyat. Jakarta

7. Notohartojo G (2015). Pemeriksaan Karies Gigi pada Beberapa Kelompok Usia oleh Petugas denganLatar Belakang Berbeda di Provinsi Kalimantan Barat. Buletin Penelitian Kesehatan. Bogor

8. Ramayanti, P. (2013). Peran Makanan Terhadap Kejadian Karies Gigi. Jurnal Kesehatan Masyarakat. Universitas Andalas. 